\title{
The Housing Cycle Theory with Regard to Housing Development in Saudi Arabia
}

\author{
Abdullah Mohammed Alghamdi \\ Dept. of Urban and Regional Planning, Faculty of Engineering, \\ King Abdulaziz University, Jeddah, Saudi Arabia
}

\begin{abstract}
This paper can be seen as a part of the on-going attempts to relate various well-established spatio-economic theories to the contemporary development in Saudi Arabia.
\end{abstract}

\begin{abstract}
After discussing the housing cycle theory and the various building programs that have been put into operation since 1970 , it is concluded that the theory, despite its relevance in certain stages, is not fully valid in explaining housing development in Saudi Arabia up to the present day (i.e., early 1990s). Indeed, state policies have produced programs for additional housing even when there was a surplus so that housing development to the present in Saudi Arabia may be seen as a line rather than a cycle. The line started with the housing shortage of the early 1970s and has continued with a surplus repeatedly seen since the early $1980 \mathrm{~s}$. The effects of these policies, together with demand-related factors, will probably determine the future pattern of housing development in Saudi Arabia.
\end{abstract}

\section{Introduction}

A theory can safely be defined as a simplified model for real life. In other words, theories help in understanding the complicated mix of operating factors.

Real life does change from place to place and from time to time, due to the many variables such as those in social, economic, and technological conditions. Accordingly, theories have to be adapted or developed to reflect the differences.

The housing cycle theory is no exception. It was formulated some 50 years ago as a means of simplifying the study of the complicated market mechanisms and stages of 
housing development. Investigating its validity with regard to housing development in Saudi Arabia since 1970 is the aim of this paper. The paper may therefore be seen in the context of a series of attempts to relate various spatio-economic theories to the actual situation in Saudi Arabia with the purpose of both contributing to knowledge and illuminating some of the operating mechanisms that may be considered by the policy makers.

\section{Research Methodology}

In order to achieve the research objective, several steps will be adopted. The housing cycle theory will first be illustratively explained and, in the context of this, an understanding of the involved mechanisms will be developed.

The second step will be to review relevant publications to see how the Saudi experience may be related to the housing cycle theory. Only the period since 1970 will be considered because that is the period for which references are available and in which major demographic and economic changes took place in Saudi Arabia.

In particular, the housing shortage and increased demand experienced in the early 1970 s will be explored. The responses of the supply mechanisms will be investigated. The case of excess supplies of housing will be shown to be that of a housing line continuing to the present day rather than part of a housing cycle because of the effect of housing supply policies.

\section{The Housing Cycle Theory}

Drawing heavily on numerous research attempts to explain the behavior of the housing market, Needleman argued that the consecutive stages of the housing market tend to be cyclic in nature ${ }^{[1]}$. To do this, he first chose the vacancy ratio as a convenient measure for the intensity of housing utilization. He then illustrated the relationship between the number of vacancies and the level of house prices in a way that would demonstrate what he called "the housing cycle" (Fig. 1).

At point $A$ (Fig. 1), prices are low and the percentage of vacancies is high, signifying a housing surplus. As the demand for houses increases - perhaps due to an increase in the number of households - the percentage of vacancies will decrease, and prices will increase slightly. Needleman also indicated that, at a certain point (say at point $B$, Fig. 1), the significant drop in vacancies in the face of the increasing demand will become so marked that it will eventually lead to higher housing prices. He suggested that, at a certain point (say at point $C$ ), housing prices will become unacceptable; probably higher than the cost of building new houses from start up. In this case, buyers will - according to him - be more likely to delay buying houses until prices decline. He believed that such hesitation was likely to bring down housing prices slightly $^{[1]}$.

Needleman continued by arguing that the high prices of houses would stimulate more active housing supply, due to the involvement of investors in the apparently profitable field of housing construction. He believed moreoever that, because both 


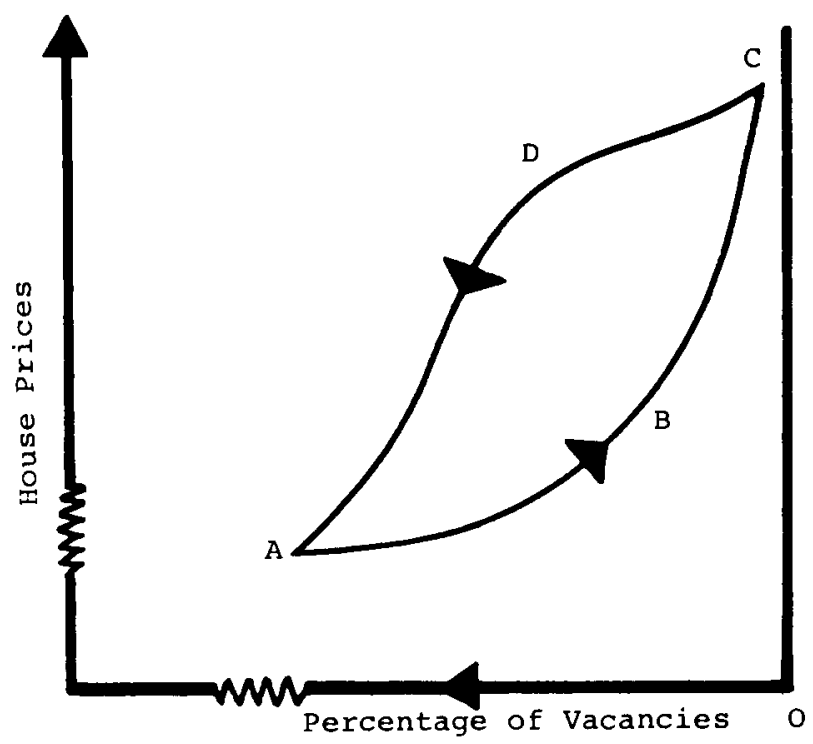

FIG. 1. Relationship between vacancies and house prices over the course of the housing cycle. Source: Ref. [1], p. 153

owners and buyers were by then accustomed to the housing shortage, the prices of houses would, for a time, remain high despite the increasing housing supply. However, he expected that, at some point further in the cycle (say at point $D$, Fig. 1), housing prices would start dropping rapidly and significantly as a result of the increasing supply. This led him to argue that the situation was likely to return to the starting point of the cycle (point $A$, Fig. 1) where prices would be low and the percentage of vacancies, due to excess housing supply, would be high.

$\mathrm{Nutt}^{[2]}$ and Cadman ${ }^{[3]}$ noticed that there was a basic difference between the market for houses and the market for durable goods. Following their ideas, one may argue that high house prices (say at point $D$, Fig. 1) still stimulate the construction of additional houses that will become ready for sale only when house prices significantly decline (say at a point near to $A$, Fig. 1). Such extensive time lags between stages in the housing market support Needleman's theory.

Figure 2 simplifies Needleman's model, in preparation for an investigation of the stages and mechanisms of Saudi housing experiences to the present. The figure suggests that the cycle will start with a housing shortage, in concurrence with a high demand. This situation will bring about high prices and rents, which will consequently encourage investment in housing construction. The involvement of many investors in such a profitable activity will eventually bring about an increase in houses which will gradually reduce prices and hence rents. Housing supply will accordingly stagnate as investors withdraw from the then unprofitable house construction. This, in turn, will bring about an eventual shortage in houses, particularly in 


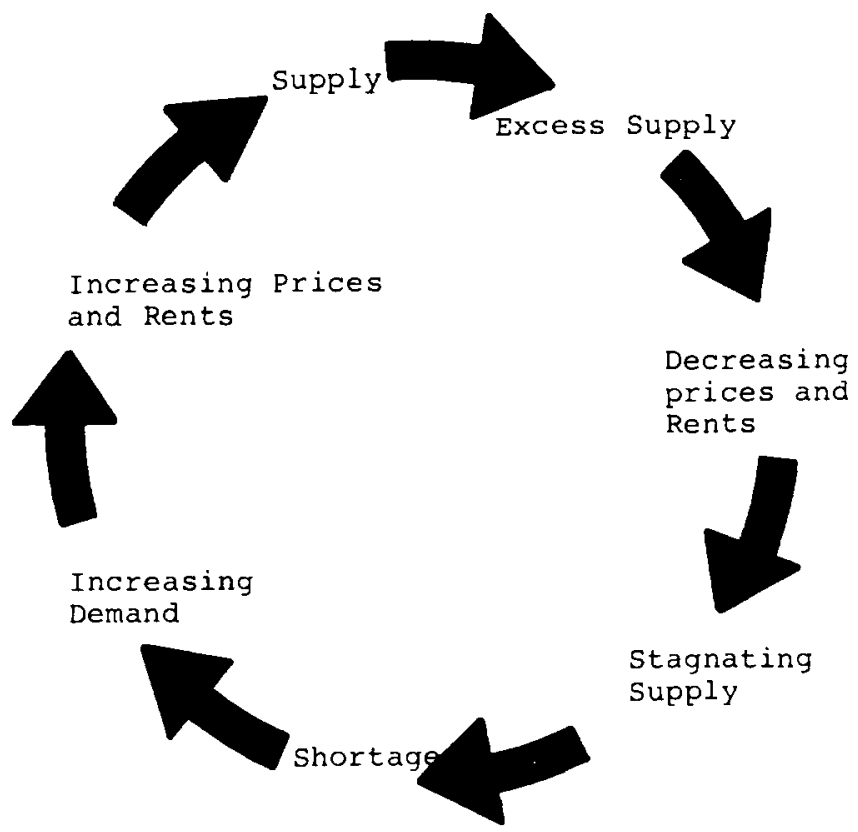

FIG. 2. Consecutive stages of the housing cycle.

cases of increased demand. The cycle will then repeat itself, with a higher level of vacancy ratio at the stages of surplus supply.

The nature and impact of the intervention of the Saudi government in housing development will next be reviewed. This will make it clear whether or not the housing cycle theory is valid in the case of Saudi Arabia.

\section{The Saudi Experiece: Brief Review}

The experience of housing markets in different Saudi localities may exhibit slightly different stages and mechanisms. However, the intention here is to briefly review the overall stages of the housing market in Saudi Arabia from the viewpoint of the consecutive stages theoretically suggested by the housing cycle (Fig. 2).

\subsection{The Early Housing Shortage and Increased Demand}

During the 1970s, Saudi Arabia experienced an acute housing shortage and, simultaneously, an increasing demand, particularly in major cities. This apparently resulted from two basic factors: The dramatic and spontaneous demographic changes and the improvement in income levels.

The population of the Saudi metropolitan centers, where development initiatives were originally concentrated, increased rapidly and dramatically over the period 1970-1980 (consult Table 1). This may safely be attributed to the large scale ruralurban migrations and the exceptionally high influx of non-Saudi labor, mainly into the Saudi cities (consult Table 2). 
TABle 1. Distribution of total population in Saudi Arabia (percentages).

\begin{tabular}{|l|c|c|c|}
\hline \multicolumn{1}{|c|}{ Area of residence } & 1970 & 1975 & 1980 \\
\hline $\begin{array}{l}\text { Shares of metropolitan centers } \\
\text { (size of } 100,000 \text { persons / center) }\end{array}$ & 20 & 35 & 42 \\
\hline Shares of small towns & 20 & 16 & 12 \\
\hline Shares of rural areas & 60 & 49 & 46 \\
\hline Total & 100 & 100 & 100 \\
\hline
\end{tabular}

Source : Ref. [4], p. 56.

TABLE 2. Nationality composition of the civilian labor force in Saudi Arabia, over the period 1980-1985.

\begin{tabular}{|c|c|c|c|c|c|}
\hline \multirow{2}{*}{ Year } & \multicolumn{2}{|c|}{ Saudis } & \multicolumn{2}{c|}{ Non-Saudis } & \multirow{2}{*}{$\begin{array}{c}\text { Total } \\
\text { (Thousands) }\end{array}$} \\
\cline { 2 - 5 } &, $000 \mathrm{~S}$ & $\begin{array}{c}\% \text { out of } \\
\text { total }\end{array}$ &, $000 \mathrm{~S}$ & $\begin{array}{c}\% \text { out of } \\
\text { total }\end{array}$ & \\
\hline 1980 & 1493.2 & 49 & 1532.8 & 51 & 3026.0 \\
\hline 1985 & 1786.0 & 40 & 2660.0 & 60 & 4446.0 \\
\hline
\end{tabular}

Note: ,000s signifies 'thousands'.

Source: Ref. [5], Adopted from Table 2-8, p. 36 .

In terms of population structure, Saudi Arabia had, by the end of the 1970s, a total population of 9.5 millions, of which 3.7 millions (or $39 \%$ ) were aged between 5 and 19 years, and 1.4 million (or $15 \%$ ) were aged between 20 and 29 years ${ }^{[6]}$. This shows the youthfulness of the population in Saudi Arabia, and implies a rapidly growing rate of family expansion.

The increase in the population and the growing rate of family expansion were accompanied by an increase in income levels. The average per capita income of the Saudi male working population increased from 4,800 Riyals in 1975 to 8,200 Riyals in 1980. Furthermore, government subsidies on food stuffs and other commodities added an average of $29 \%$ to real income levels over the same period ${ }^{[6]}$.

It is clear that the simultaneous increase in population, in the number of expanded families, and in income levels, together pushed up the demand for additional housing units, particularly in the Saudi cities. The total amount of new housing required to satisfy the demand throughout Saudi Arabia over the period 1970-1975 was estimated, in 1970 , to be 154,000 housing units ${ }^{[7]}$. Despite the unavailability of statistics, it is safe to assume that this demand was accompanied by increased housing prices and rents in accordance with the third step in the housing cycle theory (Fig. 2). Whether this situation stimulated housing supply, following the next market step in 
Needleman's housing cycle, will now be examined.

\subsection{The Government Role in Housing Development}

Of the additional 154,000 housing units that were required to satisfy the demand for housing over the period $1970-1975$, only 75,000 (or 49\%) were successfully constructed, and these came mainly through the financial support of the government ${ }^{[7]}$. The shortfall was mainly attributed to the then ineffective role of the private sector, which had difficulties due to the dramatically increased costs of building materials, labor and land over that period ${ }^{[7]}$.

The experience of the early 1970s thus proved to the Saudi government that free market conditions alone would not be able to satisfy the exceptionally increased demand for housing. On the contrary, they would bring about unfavorable conditions such as increased housing price and rent levels, and squatting. The Saudi government therefore intervened in the housing situation by :

1) Replacing, in 1975, the General Administration for Housing, which had been established four years earlier under the Ministry of Finance, by the Ministry of Housing and Public Works. Amongst its activities, the Ministry plans and implements publicly-funded housing projects, for mid- and low-income families ${ }^{[6]}$.

2) Establishing, in 1975, the Real Estate Development Fund (REDF), mainly to stimulate the activities of the private sector through granting it interest-free loans for the purpose of residential and investment house construction ${ }^{[6]}$.

3)Continuing or adopting other supporting policies such as the provision of community facilities and land grants ${ }^{[6]}$.

With reference to the stages shown by Fig. 2, an examination will now be briefly made of the supply and demand situation in housing development in Saudi Arabia since 1970. As already indicated, the Second National Plan (1975-1980) inherited a severe housing shortage. It accordingly assessed the aggregate demand for additional houses as 221,000 housing units, but - in order to be sure of achieving this total - it programmed for the construction of 225,000 housing units of which 122,100 (or $54 \%$ ) would be built by the private sector with the aid of public interest-free loans ${ }^{[7]}$.

The Third National Plan (1980-1985) estimated that the direct and indirect involvement of public sector had brought about the construction of 254,600 housing units over the period of the Second Plan (1975-1980), compared with the aim of $225,000^{[4]}$. Despite this surplus, the Third plan programmed for the construction of an additional 267,200 housing units.

The Fourth National Plan (1985-1990) estimated that, compared with the aim of 267,200 housing units, 298,400 units had actually been constructed during the period of the Third Plan (1980-1985), of which 195,000 (or 64\%) were publicly financed through loans from the REDF. In its turn, the Plan aimed at the building of an additional 285,000 housing units, in spite of concurrently planning for the repatriation of over 600,000 non-Saudis, in accordance with the Saudization strategy, which would involve many houses being vacated ${ }^{[5]}$. 


\section{The Saudi Experience and the Housing Cycle Theory: A Brief Comparison}

From the previous analysis, Needleman's theory seems to be only partially valid in explaining the Saudi housing experience up to the present day. In the initial stages of housing development (in the early 1970s), the conditions existed as described by the theory, for there was an acute housing shortage. But thenceforth Saudi experience deviated from the theory due to the failure of the free-market forces to respond effectively to the shortage. This failure can be attributed to the sudden greatly increased demand for housing in the early and mid 1970s which the Saudi private sector had neither the technical nor financial resources to meet.

In accordance with the theory, the acute housing shortage did give rise to housing supply but, while the theory emphasizes the role of the private sector as the only housing supplier, housing supply in Saudi Arabia was activated through direct and indirect state policies. These policies arose because, as has already been argued, of the failure of free market forces to meet the housing demand over the period 19701975. It therefore seems that the shortage would have continued for a longer period of time, in accordance with the theory, if the field was completely left for free market. Another distinction is that the initial supply (during the mid and late 1970s) was significant and quick in the Saudi experience, unlike the gradual and slow behavior expressed by the theory.

As already stated, the Ministry of Housing and Public Works and the REDF are the main housing supply institutions in Saudi Arabia. Increasingly, these two institutions promoted additional housing construction and this has been their most active role in Saudi development. Adopting the programs proposed by these institutions, the Saudi National Five-Year Plans have increasingly provided for additional houses. This shows why the present-day (i.e., early 1990s) situation of surplus housing in Saudi Arabia should be considered as the end of a housing line - starting with the housing shortage of the early $1970 \mathrm{~s}$ - rather than part of a housing cycle as set out in Needleman's theory. Whether or not the cycle will fully come into operation in future with regard to housing development in Saudi Arabia largely depends on the effects of further housing supply policies as well as demand-related mechanisms.

\section{Conclusion}

It is clear from the above outline that the Saudi National Plans have been accustomed to program for additional housing units, even when surplus housing supply was prevailing. This suggests that Needleman's housing cycle theory (Fig. 1 and 2), despite its relevace in certain stages, is not fully valid in explaining the housing development in Saudi Arabia up to the present (i.e., early 1990s). Furthermore, since the late 1970s, an excess housing supply has been achieved in Saudi Arabia, but that has never stimulated a consecutive housing shortage as one might have expected following Needleman's cycle. That is because government intervention through housing supply policies brought about a continuous line of development, starting with the 
stage of shortage in the early 1970s and stagnating in the present-day (i.e., early 1990s) stage of excess supply.

It then can be argued that the housing cycle theory is probably more adequate in explaining housing stages in environments where only free market forces such as supply, demand and prices regulate market mechanisms. Wherever government policies intervene, an extended time lag is likely to occur between the two stages, of excess housing supply and housing shortage, particularly in countries that favor social welfare, like Saudi Arabia. However, the length of this time lag may differ from one country to another, according to the degree of involvement which may sometimes, unlike in Saudi Arabia, be limited by financial or political factors.

\section{References}

[1] Needleman, L., The Economics of Housing, Staples Press, London, U.K., pp. 147-159 (1965).

[2] Nutt, B., Walker, B., Holliday, S. and Sears, D., Obsolescence in Housing: Theory and Applications, Saxon House, Hants, U.K., p. 3 (1976).

[3] Codman, D., Property Development, E and F.N. Spon Ltd., New York, USA, p. 11 (1983).

[4] Ministry of Planning (MOP), The Third Five-Year Plan, MOP, Riyadh, Saudi Arabia, pp. 440-443 (1980).

[5] MOP, The Fourth Five-Year Plan, MOP, Riyadh, Saudi Arabia, pp. 410-415 (1985).

[6] Ministry of Housing and Public Works, Housing for All: Commitments and Achievements in Saudi Arabia, The Planning Ministry, Riyadh, Saudi Arabia, pp. 3-12 (1987).

[7] MOP, The Second Five-Year Plan, MOP, Riyadh, Saudi Arabia, pp. 508-514 (1975). 


\section{نظريـة الدائـرة الإسكانيــة وتوفـير الإســكان في المملكة العربيـة السعوديـة}

\section{عبد الله محمد عبد الله الغامدي}

تسم التخطيط الحضري والإقليمي ، كلية الهندسة ، جامعة الملك عبد العزيز

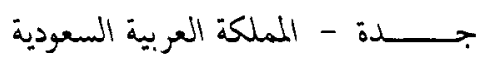

المستخلص ، ثأتي هذه المورفة ضمن محاولات مستمرة لربط نظريات تنموية ، ذات

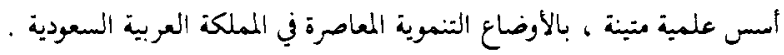

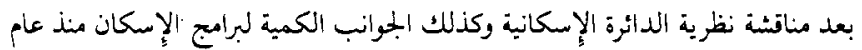

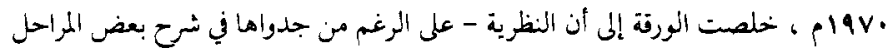

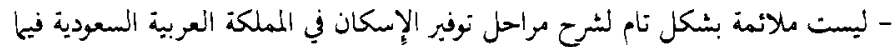

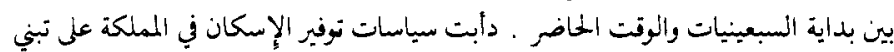

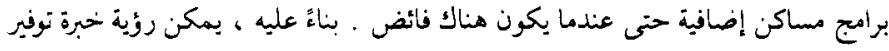

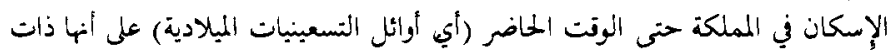

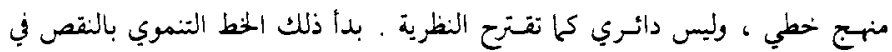

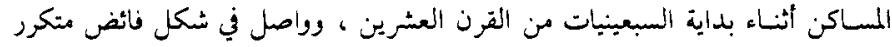

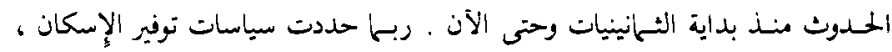

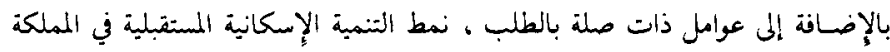

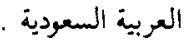

